\title{
Maintenance of the Economic Performance of Eucalyptus in Competition With Weeds
}

\author{
Kaléo D. Pereira ${ }^{1}$, Jonas E. C. Rocha ${ }^{2}$, Norberto C. Noronha ${ }^{3}$, Rafael G. Viana ${ }^{3}$, Dênmora G. Araújo ${ }^{3}$, \\ Suany C. T. Nunes ${ }^{3} \&$ Marcos A. P. Gama ${ }^{3}$ \\ ${ }^{1}$ Federal University of Viçosa, Viçosa, Brazil \\ ${ }^{2}$ Federal Rural University of Amazon, Parauapebas, Brazil \\ ${ }^{3}$ Institute of Agricultural Science, Federal Rural University of Amazon, Belém, Brazil \\ ${ }^{4}$ Federal Institute of Education, Science and Technology of Pará, Castanhal, Brazil \\ Correspondence: Kaléo D. Pereira, Department of Statistics, Federal University of Viçosa, Viçosa, Brazil. Tel: \\ 55-031-97311-1381. E-mail: kaleoef@gmail.com
}

Received: February 21, 2019 Accepted: March 27, 2019 Online Published: May 31, 2019

doi:10.5539/jas.v11n7p60 URL: https://doi.org/10.5539/jas.v11n7p60

\begin{abstract}
The aim of this study was to evaluate the growth of the hybrid clone Eucalyptus grandis $\times$ Eucalyptus urophylla submitted to competition with weeds and determine the period prior to economic loss (PPEL). The experiment was carried out in Ulianópolis, Pará State, Brazil, and consisted of the treatments continuous control and no control of weeds. Weed management was carried out by integrating both mechanical and chemical control. Stem base diameter, height, canopy diameter of eucalyptus plants were measured on the 16th month after planting. Wood volume was estimated by means of a volumetric equation. The treatments continuous control and no control of weeds were compared using the Hotelling's $\mathrm{T}^{2}$ test and the parameters for PPEL calculation were defined from volume estimation. The treatment continuous control promoted significant gains in eucalyptus growth. PPEL tended to be reduced by 3.8287 and 0.2393 units with the increase of a unit in the price of wood and the increase of planting yield, respectively. For different eucalyptus wood prices, the calculated PPEL ranged from 40 to 161 days of coexistence with weeds.
\end{abstract}

Keywords: multivariate analysis, interspecific competition, glyphosate, maximum economic performance

\section{Introduction}

The establishment of planted forests has gained increasing prominence in the forest sector, following the trend of sustainable development of wood production. Wood production from commercial reforestation generates environmental benefits by reducing pressure on native forests and their biodiversity, promotes economic gains by generating income, and fulfills a social function by creating direct and indirect jobs (Gabriel et al., 2013; Vechi \& Magalhães Júnior, 2018).

Regarding the ecological interactions, Pereira, Barroso, Albrecht, and Alves (2014) cite that the term interference encompasses the direct and indirect effects on a crop that are the result of the presence of weeds. Among the direct interferences, the most common is intra- and interspecific competition, which tends to occur from the moment that two or more individuals develop in the same space and are dependent on the same limited resources for their survival, such as water, nutrients, light, and space in the case of plants (Odum, 2004; Pereira et al., 2014). This phenomenon is one of the challenges for the success of commercial reforestation since weed occurrence damages planting productivity and leads to complications in operational activities (Pitelli, 1987; Londero, Schumacher, Ramos, Ramiro, \& Szymczak, 2012).

Weed communities can be considered as an unfavorable biotic factor of universal occurrence since they affect crops of any species, generating high management costs. An example of this is that in Brazil, in 2014, herbicide use totaled 476,860 tons, representing more than half of the amount of plant protection products marketed that year, reaching US\$ 3.90 billion (Ferreira \& Vegro, 2015). In the management of eucalyptus plantations, weed control is a factor of considerable relevance for wood productivity and final net income, representing around $20-25 \%$ of the total cost in a 7-year cycle (Rodigheri, Pinto, \& Dhlson, 2001; Queiroz \& Silva, 2016). 
Especially for eucalyptus, competition for water is highly damaging because it can cause water stress in young plants, being the most important limiting factor during the seedling establishment stage (Garau, Lemcoff, Ghersa, $\&$ Beadle, 2008). The study carried out by Toledo, Vitória Filho, Pitelli, Alves, and Lopes (2000) shows the effect of the competition on Eucalyptus urograndis, in which the individuals maintained in coexistence with weeds for 364 days suffered reductions of 70.43 and $68.56 \%$ in diameter and height, respectively, in relation to those free from weed infestation.

In eucalyptus areas, weed management is mainly performed by chemical control with glyphosate-based herbicide (Viana et al., 2010) or, less frequently, with formulations based on carfentrazone-ethyl, fluazifop-P-butyl, flumioxazin, glyphosate potassium salt, glufosinate ammonium salt, isoxaflutole, oxyfluorfen, and sulfentrazone, which are herbicides registered in the Brazilian Ministry of Agriculture, Livestock and Supply for use in the Brazilian territory (MAPA, 2018).

Because glyphosate is a nonselective herbicide, it is applied in a directed way, avoiding reaching eucalyptus plants (Machado et al., 2010). Even with precautions in the application, Tuffi Santos, Meira, Ferreira, Sant'Anna-Santos and Ferreira (2007) reported that glyphosate phytointoxications have been verified in reforestation with eucalyptus. The adequate and rational planning of weed management, besides reducing phytointoxications in plants and minimizing the heterogeneity of planting, also allow maximizing gains on productivity of the forest planting.

Some studies have already showed that during the first year of eucalyptus development there is an ideal period for weed control aiming at the best growth of the forest stand, which varies according to the clone and region of study (Toledo et al., 2000; Londero et al., 2012; Tarouco et al., 2009). Therefore, taking into account the lack of information on the management and relationship between weed and eucalyptus in the Amazon, this study aimed to evaluate the growth of the hybrid clone Eucalyptus grandis $\times$ Eucalyptus urophylla submitted to competition with weeds and determine the period prior to economic loss (PPEL) to the conditions of the Amazon region.

\section{Material and Methods}

The experiment was carried out in Ulianópolis, located in the southeastern mesoregion of the Pará State, in a plantation established in February 2013. The climate predominant in the region is Awi according to Köppen classification, with an annual average temperature around $26.3{ }^{\circ} \mathrm{C}$ and annual precipitation above $1700 \mathrm{~mm}$ (Bastos, Pachêco, Figueirêdo, \& Silva, 2005).

The soil of the experimental area is classified as medium textured Oxisol (Latossolo Amarelo Distrófico, Brazilian Soil Classification System) (EMBRAPA, 2013). Mowing, stump removal, and subsoiling operations at $60 \mathrm{~cm}$ depth were performed mechanically. Initially, the fertilization was carried out with $450 \mathrm{~kg} \mathrm{ha}^{-1} \mathrm{of} \mathrm{natural}^{-1}$ reactive phosphate applied during the subsoiling at pre-planting and, together with the planting operation, the equivalent of $150 \mathrm{~kg} \mathrm{ha}^{-1}$ of NPK with the formula $06-30-06+$ micronutrients $(0.5 \% \mathrm{~B}+0.3 \% \mathrm{Zn}+0.3 \% \mathrm{Cu})$ was applied in lateral furrows next to the plants. In addition, $1.2 \mathrm{t} \mathrm{ha}^{-1}$ of limestone was applied mechanically after seedling planting.

Experimental plots of $24 \times 24 \mathrm{~m}\left(576 \mathrm{~m}^{2}\right)$ were used with a planting spacing of $3 \times 3 \mathrm{~m}$. Two planting rows were eliminated to form the border, resulting in a useful area of $144 \mathrm{~m}^{2}$ (16 plants per plot). The experiment consisted of the treatments continuous control (CC) and no control (NC) of weeds, distributed in a randomized block design with four replications. In the treatment $\mathrm{NC}$, the eucalyptus were kept in competition with the weeds until the tenth month after planting, from which the weed control was performed with the same procedure of the treatment CC.

Weed control was performed in an integrated manner, including crowning (manual weeding) of eucalyptus plants with a radius of approximately $0.5 \mathrm{~m}$ and application of $1008 \mathrm{~g}$ a.e. ha ${ }^{-1}$ of glyphosate (Scout) using backpack sprayer equipped with an anti-drift device and set for a $200 \mathrm{~L} \mathrm{ha}^{-1}$ of spray solution volume.

Eucalyptus growth was evaluated on the 16th month after planting, in which the stem base circumference was measured with a measuring tape (converted to diameter), the total height was measured with the Haglöf clinometer, and the canopy diameter was measured with a measuring tape. Tree wood volume was estimated by means of the Husch Equation (1):

$$
\mathrm{LnV}=-9.7262+2.6417 \mathrm{LnD}
$$

where, $\mathrm{LnV}$ and $\mathrm{LnD}$ correspond to the neperian logarithm of the volume and diameter of the stem base, respectively.

For treatment comparison, the Hotelling's $\mathrm{T}^{2}$ multivariate test was performed at a 5\% significance level, in which 
the variables stem diameter, height, and canopy diameter were considered. In order to identify which variables were significantly influenced by treatments, individual confidence intervals for the Student $t$ distribution with Bonferroni protection at $5 \%$ significance were used.

PPEL (2) was calculated based on the methodology of Vidal, Fleck, and Merotto Jr. (2005):

$$
\mathrm{PPEL}=\mathrm{TC} /(\mathrm{PL} \times \mathrm{Y})
$$

where, TC is the total cost of weed control, including the fixed and variable costs, PL the daily percentage loss in eucalyptus growth due to competition, and $\mathrm{Y}$ is the eucalyptus yield, given by the product between the price of the $\mathrm{m}^{3}$ of wood and productivity.

It was considered only one procedure of weed control for and model parameterization. TC was defined from the data obtained in this study, while eucalyptus wood price was obtained from the literature. The parameter PL was obtained by the difference between the productivity in wood volume of the treatment continuous control and the treatment no control (3).

$$
\mathrm{PL}=\left[\left(\mathrm{V}_{\mathrm{cc}}-\mathrm{V}_{\mathrm{nc}}\right) / \mathrm{V}_{\mathrm{cc}}\right] / 480
$$

where, $\mathrm{V}_{\mathrm{cc}}$ corresponds to the productivity in volume of the treatment continuous control, $\mathrm{V}_{\mathrm{nc}}$ is the productivity in volume of the treatment no control, and the value 480 refers to the growth period until the evaluation. The analyses were carried out in the software R by means of the packages stats and ggplot2 (R Core Team, 2018).

\section{Results}

From the Hotelling's $\mathrm{T}^{2}$ test for treatment comparison, a significant difference was observed between the continuous control (CC) and no control (NC) of weeds. Knowing the difference between treatments, individual confidence intervals were calculated to identify in which variables a significant difference was observed between the treatments $\mathrm{CC}$ and NC. All the variables presented a significant difference between treatments since any of the intervals had the value zero (Table 1). In addition, the competition with weeds resulted in reductions in stem diameter, height, and eucalyptus canopy diameter by 56,56 , and $31 \%$, respectively.

Table 1. Upper and lower Student's $t$ individual confidence limits with Bonferroni protection of the variables base diameter $(\mathrm{D})$, height $(\mathrm{H})$, and canopy diameter $(\mathrm{CD})$ of the hybrid E. grandis $\times$ E. urophylla for the difference between the treatments continuous control (CC) and no control (NC)

\begin{tabular}{llll}
\hline Confidence limit & $\mathrm{D}(\mathrm{cm})$ & $\mathrm{H}(\mathrm{m})$ & $\mathrm{CD}(\mathrm{m})$ \\
\hline Upper & $7.27^{(1)}$ & 4.28 & 1.32 \\
Lower & 3.34 & 2.11 & 0.41 \\
\hline Treatment $^{(2)}$ & $\mathrm{D}(\mathrm{cm})$ & $\mathrm{H}(\mathrm{m})$ & $\mathrm{CD}(\mathrm{m})$ \\
\hline Continuous control $_{\text {No control }}$ & 9.53 & 5.66 & 2.75 \\
\hline $\mathrm{T}^{2}=155.71^{(3)}$ & 4.23 & 2.47 & 1.89 \\
\hline
\end{tabular}

Note. ${ }^{(1)}$ Intervals with $95 \%$ confidence; ${ }^{(2)}$ Treatment means; ${ }^{(3)}$ Significant at $5 \%$.

From the research records, the average total cost (TC) with plant control was defined in approximately 51.15 US\$ ha ${ }^{-1}$ for a glyphosate application with a manual backpack sprayer. The price of $\mathrm{m}^{3}$ of eucalyptus wood was

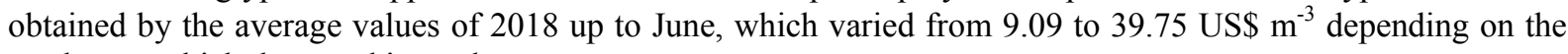
product to which the wood is used.

With the wood price and considering a productivity of $16 \mathrm{~m}^{3} \mathrm{ha}^{-1}$ up to the tenth month of eucalyptus growth, the

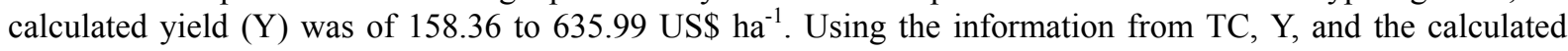
daily percentage loss (PL) of $0.2 \%$, different values were determined for the period prior to economic loss (PPEL) of eucalyptus (Table 2). 
Table 2. Period prior to economic loss (PPEL) of the hybrid E. grandis x E. urophylla as a function of the different wood prices

\begin{tabular}{llll}
\hline Product & Price $^{(1)}\left(\mathrm{US} \$ \mathrm{~m}^{-3}\right)$ & $\mathrm{Y}^{(2)}\left(\mathrm{US} \$ \mathrm{ha}^{-1}\right)$ & PPEL $\left(\mathrm{dc}^{(3)}\right)$ \\
\hline Process & 9.09 & 158.36 & 161 \\
Energy & 10.02 & 160.37 & 159 \\
Treatment & 14.60 & 233.53 & 110 \\
Sawmill & 39.75 & 635.99 & 40 \\
\hline
\end{tabular}

Note. ${ }^{(1)}$ Source: IEA (2018), means up to June with conversion to US dollar in December 2018 (US\$ $\$ 3.91$ R\$);

${ }^{(2)}$ Eucalyptus yield up to the tenth month of growth; ${ }^{(3)}$ Days of coexistence with weeds.

Table 2 shows that the highest PPEL value is that from wood for processing in the order of 161 days of coexistence, while the lowest PPEL value is for wood destined to the sawmill, with a duration of 40 days of coexistence with weeds. Therefore, the less valued the $\mathrm{m}^{3}$ of wood is, the higher the PPEL value, and vice versa. The same principle is valid for TC, which may vary depending on the density of weed infestation, which in turn should increase PL when dense or reduce PL in case of a lower density of infestation.

In addition, the calculated values of PPEL include the parameter PL and, therefore, it is assumed the coexistence of eucalyptus with weeds in all the days of PPEL. In practice, eucalyptus seedlings are transplanted to previously prepared areas and temporarily with no weeds, i.e. PPEL must then be counted from weed emergence.

When analyzing the slope coefficient of the PPEL equation as a function of eucalyptus wood price (Figure 1), there is a reduction of 3.8287 units in PPEL with the variation of one unit in wood price. In the case of the economic performance of the planting, PPEL reduced by 0.2393 units for each unit increased in the yield (Figure 2).

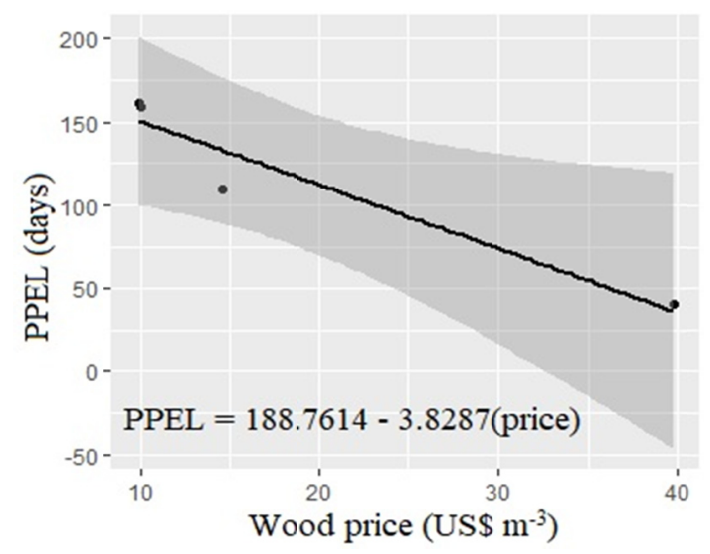

Figure 1. Variation of PPEL as a function of the wood price of E. grandis $\times E$. urophylla with confidence intervals represented by the gray margin 


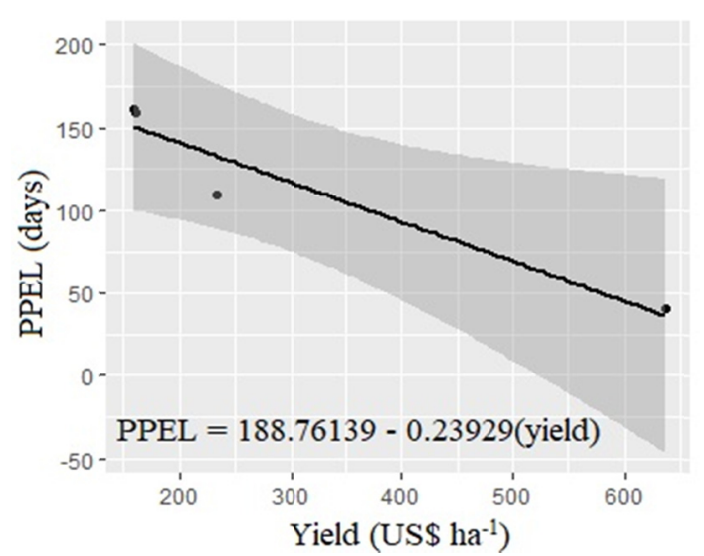

Figure 2. Variation of PPEL as a function of planting yield of E. grandis $\times E$. urophylla with confidence intervals represented by the gray margin

\section{Discussion}

The fact that the treatment $\mathrm{NC}$ resulted in lower average values when compared to $\mathrm{CC}$ was an expected result since studies on eucalyptus in competition with weeds have indicated a negative effect on forest species growth (Costa, Alves, \& Pavani, 2004; Aparício, Ferreira, Silva, Rosa, \& Aparício, 2010). W. Silva, Sediyama, A. A. Silva, and Cardoso (2004) studied the efficiency of water use in eucalyptus and observed that seedlings of $E$. citriodora and E. grandis grown together with the grass Urochloa brizantha in pots showed a reduction in dry biomass accumulation regardless of soil water content.

In a study evaluating the growth of $E$. grandis under competition with different densities of $U$. decumbens, Toledo et al. (2001) verified that eucalyptus plants coexisting with this grass at densities higher than 4 plants $\mathrm{m}^{-2}$ for 90 days had average reductions in the number of leaves, dry biomass of leaves, stem, and branches, and leaf area by 70.65, 55.30, 55.22, 77.29, and 63.26\%, respectively. Costa, Alves, and Pavani (2002) analyzed the effects of interference periods of oval-leaf false buttonweed (Spermacoce latifolia) on E. grandis growth and observed a reduction of $20 \%$ in the leaf area after 20 days of competition, 10 and $8 \%$ reduction in the number of leaves and branches, respectively, at 40 days of coexistence, and a reduction of 36,26 , and $18 \%$, in the dry biomass of branches, stem, and leaves, respectively, from 20 days of coexistence.

Tarouco et al. (2009) worked with the concept of period prior to interference (PPI) and reached the conclusion that weed management should be carried out at 107 days after planting E. urograndis seedlings. On the other hand, Londeiro et al. (2012) observed that from 56 days and at least 140 days after planting the eucalyptus should be free of competition. Changes in control periods observed in different studies are related to different environmental conditions, use of different species or clones, and specificities in the floristic composition of weed communities (Toledo et al., 2003).

In practice, PPEL calculation generated results that varied according to product price, cost of weed control, planting yield, and crop resistance to competition. Changes in any of these components modify the results of PPEL even though the others are constant, as shown by Vidal et al. (2005) for corn and soybean.

It is important to highlight that PPEL is part of a context of analysis that involves mostly economic aspects, which are related not only to reductions of losses in crop productivity but also to the effectiveness of weed community control. In this sense, specifically for chemical control, some factors must be taken into account, such as water regime, since plants under water stress conditions may present reduced phytotoxicity after herbicide application (Pereira et al., 2012). Other factors also influence herbicide efficiency, such as light, temperature, relative air humidity, application technology, applicator training, and used active principle and formulation (Silva, F. A. Ferreira, \& L. R. Ferreira, 2007a; Silva, F. A. Ferreira, \& L. R. Ferreira, 2007b; L. R. Ferreira, F. A. Ferreira, \& Machado, 2007).

\section{Conclusion}

For the edaphoclimatic conditions of this study, PPEL values obtained for the hybrid Eucalyptus grandis $\times$ Eucalyptus urophylla ranged from 40 to 161 days of coexistence with weeds. The increase in PPEL occurred inversely proportional to wood price, planting yield, and fragility of eucalyptus to competition. A continuous weed control favored eucalyptus growth when compared to the cultivation without weed control. 


\section{Acknowledgements}

To Federal Rural University of Amazon for the logistical support and concession of research grants.

\section{References}

Aparício, O. S., Ferreira, R. L. C., Silva, J. A. A., Rosa, A. C., \& Aparício, W. C. S. (2010). Weed control in two clones of Eucalyptus $\times$ urograndis in Amapá. Ciência Florestal, 20(3), 381-390. https://doi.org/10.5902/ 198050982053

Bastos, T. X., Pachêco, N. A., Figueirêdo, R. O., \& Silva, G. F. G. (2005). Agroclimatic characteristics of the Municipality of Paragominas. Belém: Embrapa Amazônia Oriental.

Costa, A. G. F., Alves, P. L. C. A., \& Pavani, M. C. M. D. (2002). Periods of interference of Spermacoce latifolia on the initial growth of Eucalyptus grandis. Scientia Forestalis, 61, 103-112.

Costa, A. G. F., Alves, P. L. C. A., \& Pavani, M. C. M. D. (2004). Periods of Commelina benghalensis interference in the initial growth of Eucalyptus grandis. Revista Arvore, 28(4), 471-478. https://doi.org/ 10.1590/S0100-67622004000400001

EMBRAPA. (2013). Brazilian system of soil classification (3rd ed.). Brasília: EMBRAPA.

Ferreira, C. R. R. P. T., \& Vegro, C. L. R. (2015). Agricultural defenses: in 2014 the billing was the highlight. Análises e Indicadores do Agronegócio, 10(5).

Ferreira, L. R., Ferreira, F. A., \& Machado, A. F. L. (2007). Herbicide application technology. In A. A. Silva, \& J. F. Silva (Eds.), Weed Management Topics. Viçosa: Editora UFV.

Gabriel, V. A., Vasconcelos, A. A., Lima, E. F., Cassola, H., Barretto, K. D., \& Brito, M. C. (2013). The importance of eucalyptus plantations in biodiversity conservation. Pesquisa Florestal Brasileira, 33(74), 203-213. https://doi.org/10.4336/2013.pfb.33.74.435

Garau, A. M., Lemcoff, J. H., Ghersa, C. M., \& Beadle, C. L. (2008). Water stress tolerance in Eucalyptus globulus Labill. subsp. maidenii (F. Muell.) saplings induced by water restrictions imposed by weeds. Forest Ecology and Management, 255, 2811-2819. https://doi.org/10.1016/j.foreco.2008.01.054

IEA. (2018). Forestry Markets. Retrieved from http://www.iea.sp.gov.br/out/floresta.html

Londero, E. K., Schumacher, M. V., Ramos, L. O. O., Ramiro, G. A., \& Szymczak, D. A. (2012). Influences of different control periods and coexistence with weed in eucaliptus. Cerne, 18(3), 441-447. https://doi.org/ 10.1590/S0104-77602012000300011

Machado, A. F. L., Ferreira, L. R., Santos, L. D. T., Ferreira, F. A., Viana, R. G., Machado, M. S., \& Freitas, F. C. L. (2010). Photosynthetic efficiency and water use in eucalyptus plants sprayed with glyphosate. Planta Daninha, 28(2), 319-327.

MAPA. (2018). Phytosanitary Agrochemicals System. Retrieved form http://agrofit.agricultura.gov.br/agrofit_ cons/principal_agrofit_cons

Odum, E. P. (2004). Fundamentals of Ecology (6th ed.). São Paulo: Fundação Calouste Gulbenkian.

Pereira, F. C. M., Barroso, A. A. M., Albrecht, A. J. P., \& Alves, P. L. C. A. (2014). Literature review weed interference: concepts and examples in eucalyptus. Journal of Agronomic Sciences, 3, 236-255.

Pereira, M. R. R., Martins, D., Souza, G. S. F., Rodrigues-Costa, A. C. P., \& Klar, A. E. (2013). Efficacy of herbicides applied to Digitaria horizontalis plants under different water conditions. Planta Daninha, 30(1), 165-172. https://doi.org/10.1590/S0100-83582012000100019

Pitelli, R. A. (1987). Competition and control of weeds in agricultural areas. Série Técnica IPEF, 4(12), 1-24.

Queiroz, A. M., \& Silva, Z. A. G. P. G. (2016). Economic aspect of eucalyptus plantation (Eucaliyptus ssp.) in Baixo Acre region. Floresta, 46(3), 287-296. https://doi.org/10.5380/rf.v46i3.42931

R Core Team. (2018). R: A language and environment for statistical computing. R Foundation for Statistical Computing, Vienna.

Rodigheri, H. R., Pinto, A. F., \& Dhlson, J. C. (2001). Eucalyptus production, productivity and income cost driven for multiple use in the pioneer north of the State of Paraná. Colombo: Embrapa Florestas.

Silva, A. A., Ferreira, F. A., \& Ferreira, L. R. (2007). Herbicides: Classification and mechanisms of action. In A. A. Silva, \& J. F. Silva (Eds.), Weed Management Topics. Viçosa: Editora UFV. 
Silva, J. F., Silva, J. F., Ferreira, L. R., \& Ferreira, F. A. (2007). HERBICIDES: absorption, translocation, metabolism, formulation and mixtures. In A. A. Silva, \& J. F. Silva (Eds.), Weed Management Topics. Viçosa: Editora UFV.

Silva, W., Sediyama, T., Silva, A. A., \& Cardoso, A. A. (2004). Consumption and water efficiency use index by Eucalyptus citriodora and E. grandis plants cultivated in pots containing soil with three water contents in the soil jointly with different Brachiaria brizantha populations. Floresta, 34(3), 325-335.

Tarouco, C. P., Agostinetto, D., Panozzo, L. E., Santos, L. S., Vignolo, G. K., \& Ramos, L. O. O. (2009). Weed interference periods on in the initial growth of eucalyptus. Pesquisa Agropecuária Brasileira, 44(9), 1131-1137. https://doi.org/10.1590/S0100-204X2009000900010

Toledo, R. E. B., Dinardo, W., Bezutte, A. J., Alves, P. L. C. A., \& Pitelli, R. A. (2001). Effect of Brachiaria decumbens Stapf density on the initial growth of Eucalyptus grandis W.Hill ex Maiden plants. Scientia Forestalis, 60, 109-117.

Toledo, R. E. B., Vitoria Filho, R., Bezutte, A. J., Pitelli, R. A., Alves, P. L. C. A., Valle, C. F., \& Alvarenga, S. F. (2003). Brachiaria sp. free periods and effects on the productivity of Eucalyptus grandis. Scientia Forestalis, 63, 221-232.

Toledo, R. E. B., Vitória Filho, R., Pitelli, R. A., Alves, P. L. C. A., \& Lopes, M. A. F. (2000). Effects of weed control periods on initial growth and development of eucalypt. Planta Daninha, 18(3), 395-404. https://doi.org/10.1590/S0100-83582000000300002

Tuffi Santos, L. D., Meira, R. M. S. A., Ferreira, F. A., Sant'Anna-Santos, B. F., \& Ferreira, L. R. (2007). Morphological responses of different eucalypt clones submitted to glyphosate drift. Environmental and Experimental Botany, 59, 11-20. https://doi.org/10.1016/j.envexpbot.2005.09.010

Vechi, A., \& Magalhães Júnior, C. A. O. (2018). Positive and negative aspects of eucalyptus culture and the environmental effects of their cultivation. Revista Valore, 3(1), 495-507. https://doi.org/10.22408/ reva312018101495-507

Viana, R. G., Tuffi Santos, L. D., Demuner, A. J., Ferreira, F. A., Ferreira, L. R., Ferreira, E. A. ... Santos, M. V. (2010). Quantification and Chemical Composition of Epicuticular Wax of Eucalyptus Leaves. Planta Daninha, 28(4), 753-758. https://doi.org/10.1590/S0100-83582010000400007

Vidal, R. A., Fleck, N. G., \& Merotto Jr., A. (2005). Weedy period prior to economic loss (WEEPPEL): A new approach to weedy and weed-free periods. Planta Daninha, 23(3), 387-396. https://doi.org/10.1590/ S0100-83582005000300001

\section{Copyrights}

Copyright for this article is retained by the author(s), with first publication rights granted to the journal.

This is an open-access article distributed under the terms and conditions of the Creative Commons Attribution license (http://creativecommons.org/licenses/by/4.0/). 